\begin{tabular}{lll}
\hline & Yönetim, Ekonomi, Edebiyat, & JOMELIPS - Journal of \\
Review Article & $\begin{array}{l}\text { Islami ve Politik Bilimler } \\
\text { Dergisi,2(1): 95-104, }\end{array}$ & $\begin{array}{l}\text { Management Economics Literature } \\
\text { Islamic and Political Sciences }\end{array}$ \\
Derleme Makale & 30 Haziran/June, 2017 & e-ISSN :2547-9512 \\
DOI: 10.24013/jomelips.321655 & . & \\
\hline
\end{tabular}

\title{
Mikrofinansman Kurumu Örneği: Grameen Bank
}

\author{
Dr. Nurhodja Akbulaev ${ }^{*}$ Öğr. Gör. Turan Ahmedov² Öğr. Gör. Yusif Aliyev ${ }^{3}$
}

\begin{abstract}
${ }^{1}$ Azerbaycan Devlet İktisat Üniversitesi-UNEC, Türk Dünyası İşletme Fakültesi, İktisat ve İşletme Bölümü,
${ }^{2}$ Azerbaycan Devlet İktisat Üniversitesi-UNEC, Türk Dünyası İşletme Fakültesi, İktisat ve İşletme Bölümü,

${ }^{3}$ Azerbaycan Devlet İktisat Üniversitesi-UNEC, Türk Dünyası İşletme Fakültesi, İktisat ve İşletme Bölümü,
\end{abstract}

\section{$\ddot{\mathbf{O z}}$}

Bugünün gelişmekte olan dünyasında, yoksul kesimin yaşam standartları yükseltilmedikçe, hiçbir ülkede anlamlı bir kalkınmanın sağlanamayacağı gerçeğini açık bir şekilde kabul edilmiştir. Yoksul kesimin yaşam refahını yükseltme düşüncesi giderek ön plana çıkmaktadır; çünkü sadece büyüme yönlü stratejiler, insanların yaşam şartlarını iyileştirme konusunda önemli ölçüde başarısız olmuşlardır. $\mathrm{Bu}$ çalışmada mikrofinans uygulamalarında en başarılı mikrofinansman kurumu olan Grameen Bank'ın ortaya ve gelişimi, amacı ve hedef kitlesi, kurumsal ve faaliyet yapısı, yenilikleri ve finansal yapısı üzerinde durulmuştur. Ayrıca, Grameen Bank sistemleri müşteri türleri, finansal hizmet çeşitleri ve şartları bağlamında ayrıntılı olarak açıklanmıştır. Bu çalışmada, Grameen Bank'ın ortaya çıkışı, tarihsel gelişimi, verdiği finansal hizmetler, hizmetinden faydalanan alanlara göre müşteri kesimi ve finansal yapısı hakkında bilgi sunulmuştur.

Anahtar kavramlar: Grameen Bank, Yoksulluk, Mikrokredi, Mikrofinans, Bankacılık

\section{Micro Finance Corporation Sample: Grameen Bank}

\begin{abstract}
In today's developing world, it is clearly accepted that unless the standards of living of the poor are raised, no meaningful development can be achieved in any country. Poverty is increasingly at the forefront of raising the living prosperity; Because only growth-oriented strategies have been largely unsuccessful in improving people's living conditions. This study focused on the development and development of Grameen Bank, the most successful microfinance institution in microfinance applications, the aim and target mass, institutional and activity structure, innovations and financial structure. In addition, Grameen Bank systems are described in detail in terms of customer types, financial services types and conditions. In this study, information on the customer segment and financial structure of Grameen Bank is presented according to the use of the service, its historical development, the financial services it has provided, and its services.

*Sorumlu Yazar (Corresponding Author):

Nurhodja AKBULAEV; Azerbaycan Devlet İktisat Üniversitesi UNEC Türk Dünyası İşletme Fakültesi İktisat ve İşletme Bölümü, E-mail: nurhoca@gmail.com

Geliș (Received) : 10.05 .2017

Kabul (Accepted) : 29.06.2017

Basım (Published) : 30.06.2017
\end{abstract}


Key words: Grameen Bank, Poverty, Microcredit, Microfinance, Banking

\section{Giriş}

Mikrofinans sistemi, başlangıçta geleneksel bankacılıktan farklı şekilde faaliyete başlamasına rağmen ticaret bankaları tarafından da benimsenmiştir. Ancak, yüksek maliyetlerinden dolayı geniş kapsamlı kullanılamamaktadır. Mikrofinans yoluyla verilen borç tutarlarının küçük tutarda olması, borç verme süresinde uygulanan işlem maliyetlerinin yüksek olması ve müşterilerinin büyük bir kısmı kırsal bölgelerde olmaları nedeniyle şube açma masraflarından kaçınmaktadırlar. Uygulama sadece yoksullukla mücadele ile sınırlı kalmayıp, köylerden şehre ya da gelişmiş ülkelere göçleri de büyük çapta azaltma özelliğine sahiptir. Özellikle kırsal bölgelerde hayvancılık ve balıkçılığın, tarımcılık ve ormancılığın finanse edilmesi hem istihdam oluşturacak hem de bölgesel kalkınmayı sağlayacaktır. Bu olumlu sonuçlara ulaşmak için uygulama modelinin sağlıklı oluşturulması ve buna göre uygulanması gerekmektedir. Uzun vadeli fon sağlayan finans kurumları birçok sektörün can damarı olduğu gibi, mikrofinans kurumlarının da varlığını sağlıklı ve sürekli bir şekilde sürdürebilmesi tüm dünya ekonomilerinde önemli yere sahip olan küçük işletmelerin gelişiminin ve yoksulların refah seviyesinin yükseltilmesinin finansmanı açısından oldukça önemlidir. Söz konusu kurumların süreklilik kazanması için sosyal amaçlı hizmetleri ve kazanç açılarından birbirinden farklı finansal hizmetlerin sağlamaları gerekmektedir. Bununla sosyal ve ticari yönden yeni aktivitelere girişmek, hem dolaylı ya da dolaysız gelirlerine katkıda bulunmak hem de ekonomik kalkınmaya rehberlik yapmak bu kurumların başlıca görevidir. Bankacılığın tarihsel gelişimi incelendiğinde çok eskilere dayanan tarihi, çeşitli yapıları ve uygulamalarına rastlanmaktadır. Bu tür uygulamaları içerisinde çiftçilere yönelik kredi kooperatifleri şeklinde uygulamalar olmuştur. Ancak, küçük tutarlardaki kredi uygulamaları zamanla gelişmiş sanayi ülkelerinde büyük bankalara dönüşmüş, gelişmekte ve geri kalmış ülkelerde de faaliyetlerini sürdürememişlerdir. Söz konusu küçük miktarlardaki kredi uygulamalarıyla dünyanın dört bir yanına yayılarak model olarak kullanılan Grameen Bank en başarılı yoksul bankasıdır. Grameen Bank ayrıca ülkenin önemli ve temel sektörlerinden olan tarım sektöründeki çiftçileri de desteklemektedir.

Tarımsal destekleme politikalarının nitelik ve niceliğindeki bu değişmeler, kırsal kesimde üretimden yabancılaşmaya ve yoksulluğa yol açarken,kırmızı ette olduğu gibi ülkeyi tarımsal ürün ithal eder bir konuma getirmiştir (Kandemir, 2011: 103). 2000 yılından sonra Dünya Bankası'nın talebiyle uygulanan ve OTP'na uyumun anahtarı olarak gösterilen doğrudan gelir desteğine yönelik politikalar, kendi kendine yeterli Türk tarımını olumsuz etkilemiştir. Nüfusu \%25'inin istihdam edildiği tarım sektöründe, DGD uygulamaları ile desteklerin üretim yerine arazi büyüklüğüne göre verilmesi, kırsal kesimde yoksulluğu arttırarak kentlere gö̧̧ sürecini hızlandırmıştır (Kandemir, 2011: 110-111). TÜiK (2009)'e göre istihdamdaki fertler için tarım sektöründe yoksulluk oranı $\% 33$ iken, sanayi ve hizmet sektöründe bu oranlar sırasıyla $\% 9,6$ ve $\% 7,2$ olarak gerçekleşmiştir.

\section{Yoksulluk Kavramı ve Türleri}

Yoksulluk olgusu, insan tarihinde hep var olan bir olgudur. Bunun çözümü için birçok program ve modeller geliştirilmeye çalışılmış ve halen üzerinde araştırmalar yapılmaktadır. Bu olgu bundan sonra da devam edecektir. Ancak, işletmeler riskten kurtulamadıkları gibi yoksulluğun da tam bir çözümü olsa bile uzun bir zaman gerekmektedir. Söz konusu amaçla geliştirilmekte olan program ve modeller tamamen yoksulluğu yok edememesine rağmen azalmasına sebep olmaktadır. 


\subsection{Yoksulluk Kavramı}

Her dünya görüşünün yoksulluk kavramına farklı yaklaşması nedeniyle yoksulluk kavramının tanımlanması oldukça güçtür. Yoksulluk kavramı ile ilgili literatür farklı görüşler yer alsa da, kavram ve türleri açısından bazı ortak noktalara rastlamak mümkündür.

Sözlük anlamıyla yoksul, yeterli düzeyde parası olmayan veya konforlu bir şekilde yaşamak için gerekli olan araçlara sahip olamayan kişidir. Yoksulluk kelimesi ise yaşamın gerektirdiği olanaklardan yoksun olma durumunu ifade etmektedir. Yaşamı sürdürmek için gerekli olan şeyler ise, içinde bulunulan topluma, çevreye ve koşullara bağlı olarak değişiklik göstereceğinden yoksulluk kavramı her zaman gözlemlenen durumla, standart durumun karşılaştırılmasını gündeme getirir (Aktan ve Vural, 2002). Sosyal siyaset açısından yoksulluk, insan haysiyetine ve şahsiyetine yaraşır bir hayat düzeyinin altında, maddi yönden tam anlamıyla veya nispi olarak yetersiz olma durumudur. Bir başka ifadeyle, toplum, ahlak, aile ve kültür hayatımızı tehdit eden bir felaket, umumi bir toplumsal risktir (Seyyar, 2002: 171).

İnsanlar topluluklar halinde yaşamaya ve üretim ilişkilerinde bulunmaya başladığından bu yana yoksulluk hep var olmuştur. Yoksulluğun kökenlerinin ana hatlarıyla sosyal bir sorun olarak ortaya çıkışını 17. yy başlarından izlemek mümkündür. Başta liberalizmin en büyük teorisyeni ve öncüsü olan John Locke olmak üzere 17. yy. liberal kuramcılarının en baştan yoksulluk sorununa eğilerek özel mülkiyet haklarını savunurken bunun yoksulları dışlamaması gerektiğini, geçimlik yaşam hakkının sosyal düzenin güvenliği açısından gerekli olduğu ve bunun toplumun, yoksulların refahını sağlayacak bir artış oluşturulmasıyla sağlanabileceği yaklaşımı içinde olduklarından söz edilebilmektedir (Şenses, 2001:32).

Önemli düşünür ve kuramcıların, yoksulluk sorununa yakın ilgisinin sanayileşmeye dayalı kapitalizmin kök salmaya ve yaygınlaşmaya başladığı 18. ve 19. yy.'da giderek arttığı gözlenmektedir (Şenses, 2001: 33). Zira 18. yy’ın ortalarında kapitalist yörüngede gelişen sanayi devrimi her ne kadar emeğin verimliliğini olağanüstü arttırıp, kitlesel üretime geçiş imkânları sağlayan insanlık tarihinin büyük dönüşümlerinden biri olsa da beraberinde kentleşme, nüfus artışı, kitlesel bir toplum, hızla sanayileşen toplumların daha yoğun emperyalist politikalar izlemesi ve hızla sanayileşen ülkeler arasında yoğun rekabeti de beraberinde getirerek yoksulluk sorununu önemli bir toplumsal sorun olarak ortaya çıkarmıştır.

\subsection{Yoksulluk Kıstasına Göre Yoksulluk Türleri}

Yoksulluk ile ilgili edebiyatlar ve araştırmalar incelendiğinde yoksulluk türleri ölçüm tekniklerine göre üç gruba ayrılmaktadır. Söz konusu gruplar, mutlak yoksulluk, göreli yoksulluk ve insani yoksulluk şeklinde siralanmaktadır.

a. Mutlak Yoksulluk ve Ölçülmesi 
Mutlak yoksulluk; hane halkının ya da bireyin asgari yaşam düzeyini sürdürebilmesi için gerekli, yalnızca en temel ihtiyaçlarını karşılayabilmesi durumudur. Birinci dereceden yardıma muhtaç olarak algılanması gereken bu fakirler temel insani ihtiyaçlarını bile karşılayamamakta, hatta bu duruma düşen bir kişiye dışarıdan yardım edilmediği taktirde ölüm riskiyle bile karşı karşıya gelmesi de kaçınılmaz olabilmektedir. Mutlak yoksulluğun ortaya çıkarılması bireylerin yaşamlarını sürdürebilmeleri için gerekli olan minimum tüketim ihtiyaçlarının belirlenmesini gerektirir. Mutlak yoksulluk gıda ve gıda dışı bileşenler dikkate alınarak ayrı ayrı belirlenebilmektedir (www.tuik.gov.tr). Sadece gıda harcamalarını esas alan mutlak açlık sınırının hesaplanması; "asgari temel gıda maddesinden oluşan gıda sepetinin maliyetiyle" hesaplanmaktadır. Tüm nüfus için önerilen kişi başına günlük alınması gereken kalori miktarı esas alınarak, bunun altında kalori alan fertler bir yoksulluk çizgisi oluşturmaktadırlar. Mutlak yoksulluk sınırı gıda harcamalarına ek olarak temel gereksinimleri de (eğitim, sağlık, barınma, giyim) dikkate alınarak da hesaplanabilmektedir. Günümüzde birçok Az Gelişmiş Ülkede bu yaklaşım (Temel İhtiyaçlar Yaklaşımı) temel alınarak mutlak yoksulluk sınırı hesaplanmaktadır.

\section{b. Göreli Yoksulluk ve Ölçülmesi}

Adam Smith' in tanımına göre, temel ihtiyaçlarını mutlak olarak karşılayabilen ancak kişisel kaynakların yetersizliği yüzünden toplumun genel refah düzeyinin altında kalan ve topluma sosyal açıdan katılımları engellenmiş olanlar göreli yoksullardır. Tanımdan da anlaşılacağı gibi, yoksulluğu göreli bir kavram olarak yorumlayan ve sosyal yönü daha fazla olan göreli yoksulluk, yoksulluğu bireyin gereksinmelerini karşılama derecesi yönüyle toplumun diğer bireyleri karşısındaki durumuna göre tanımlamaktadır. Yoksulluğun göreli olarak tanımlanmasında ya nüfusun düşük gelirli bir oranı yoksul olarak alınmakta ya da ortalama gelir düzeyinde bir sınır saptanarak bu sınırın altında gelire sahip olanlar yoksul olarak tanımlanmaktadır. Mutlak yoksulluk tanımlarını, kişi başı sabit bir reel gelir (harcama) düzeyi temelinde yaparken; göreli yoksulluk başka bazı sosyal grupların kişi başı reel geliri (ya da harcaması) şeklinde tanımlar, göreli yoksulluk kavramı farklı grupların sahip olduğu mutlak gelir düzeyinden daha ziyade gelir ve refahın dağılımındaki farklılıklara odaklanır. Göreli yoksulluk çizgisi hesaplanırken atılacak ilk adım araştırmanın yapılacağı sosyal topluluğun ortalama refah seviyesinin belirlenmesidir. Bu aşamada refah ölçüsü olarak hem gelir düzeyi hem de tüketim düzeyi belirlenebilir. Daha sonra bu düzeyin belli bir oranı ise yoksulluk çizgisini vermektedir (Arpacıŏlu ve Yıldırım, 2011:63).

\section{c. İnsani Yoksulluk}

Birleşmiş Milletler Kalkınma Programı (UNDP) yoksulluk ve yoksulluğun ölçülmesi yaklaşımlarını genişleterek katkıda bulunmuştur. UNDP' nin 1997 İnsani Gelişme Raporu (IGR) ile ilk defa 'İnsani Yoksulluk" kavramını ortaya atmıştır. İGR 1990 yılından bu yana UNDP tarafından her yıl yayımlanmaktadır. UNDP hazırladığı söz konusu raporlarda; insani gelişme kavramını, kişi başı gelir hesaplarının ötesine giderek insan kaynaklarının gelişimini, insanı insan yapan özgürlük, kişilik gibi unsurları ve insanın temel gereksinimlerine ulaşma düzeyini bir arada değerlendirmekte ve böylece kalkınma içindeki insanın rolünü ele almaya çalışmaktadır (Demir, 2006: 2). Temel insan yeteneklerini sürdürebilecek olan mal, hizmet ve altyapıya, enerji, hijyen, eğitim, iletişim, içme suyu ve erişimin yokluğu ya da kısıtlanması yoksulluğun "insanî" boyutu olarak nitelendirilmektedir (Bayındırlık ve İskan Müdürlüğü, 2009).

İnsani Gelişme Raporu'nda insani gelişme, kişilerin seçeneklerini artırma süreci olarak tanımlanmaktadır. $\mathrm{Bu}$ seçenekler sonsuz ve değişken olabilmekte, ancak bütün gelişme aşamalarında üç temel seçenek ön 
plana çıkmaktadır. Bu seçenekler; a) Uzun ve sağlıklı bir yaşam, b) Bilgi edinme c) Tatminkâr bir yaşam sürmeyi sağlayacak kaynaklara ulaşmaktır (UNDP, 2001: 9). Bunların dışında, siyasi özgürlük, garanti edilmiş insan hakları ve öz saygınlık da diğer seçenekler arasındadır. Bu anlayışa göre gelir, insani gelişmişliğin göstergesi olarak önemli bir faktör olmakla beraber tek başına yeterli olmamaktadır. Kişisel gelir yanında, kredi olanaklarına, kamu mallarına ve verimli üretim araçlarına erişim, akraba ve arkadaşlardan sağlanan transferler gibi insanların kaynaklara erişim düzeyinin bir bütün olarak değerlendirilmesini amaçlamaktadır (Şenses, 2001:101). Özellikle insani gelişmişliğin ölçümünde kullanılan göstergeler ve bunların bileşik ifadesi olan endeksler bu alanda insanlık adına çok büyük bir ilerlemedir.

Bu bağlamda UNDP insani gelişmeyi, sağllk ve eğitim gibi gelişmenin ekonomik olmayan göstergelerini de dikkate alarak İnsani Gelişme Endeksi (IGGE) ile ölçmektedir. Benzer İGE değerlerine sahip iki ülke arasında kişi başı GSYIHH arasında ciddi farklılık olsa da bu durum, İGE'nin hesaplanmasında insani gelişmişliğin ekonomik olmayan yönlerinin de hesaba katılmasından kaynaklanmaktadır (Demir, 2006: 4).

İGE hesaplama yöntemi üç kritere dayanmaktadır. Bunlar; refah standardı, eğitim standardı ve sağlık standartıdır. Refah standardı tatminkâr bir yaşam sürmeyi sağlayacak kaynaklara ulaşmaya, sağlık standardı uzun ve sağ lıklı bir yaşama, eğitim standardı ise bilgi edinmeye karşılık gelmektedir.

UNDP'nin hazırladığı İGR' de, İGE' nin yanı sıra yayınlanan İnsani Yoksulluk Endeksi, Toplumsal Cinsiyeti Güçlendirme Endeksi, Cinsiyete Bağlı Gelişme Endeksi ile ülkelerin sosyal gelişmişlik düzeyi daha iyi belirlenmeye çalışılmaktadır (Demir, 2006: 5).

\section{Mikrofinans Sisteminin Esasları}

Özellikle 1900'lerin ikinci yarısından sonra gerek ülkelerin gerekse Birleşmiş Milletler, Dünya Bankası ya da OECD gibi uluslar arası kuruluşların, gelişmekte olan ülkelerdeki yoksullukla mücadele ve sürdürülebilir kalkınmanın sağlanması amaçlarıyla makro düzeyde hazırladıkları stratejilerin geçen zaman zarfinda anlamlı başarılar kaydedememesi, bir yandan söz konusu stratejilerin yeniden gözden geçirilmesi ile sonuçlanırken diğer yandan ülkelerin arzulanan amaçlara istikrarlı bir biçimde ulaşmalarını hedefleyen yeni yaklaşımların doğuşuna zemin hazırlamıştır.

Diğer bir ifadeyle, bir ülkede üretim sürecinde yer almayan ve mevcut koşullarda hiçbir finansal kuruluştan istifade edemeyecek durumda olan en fakir grubun geniş bir yelpazede çeşitli kamu ve özel sektör kuruluşlarınca sunulan finansal olanaklardan yasal olarak yararlandırılmaları esasına dayanan mikrofinans sistemi, bir yandan söz konusu bireylerin ekonomik anlamda bağımlı konumlarından kurtulup onları üretken hale getirerek düzenli bir gelir sahibi olmalarını teşvik etmekte, diğer yandan üretim sürecine katılan yeni işgücü sayesinde mevcut üretim kapasitesini ve dolayısıyla çıktı seviyesini arttırarak büyüme ve kalkınma gibi diğer makro ekonomik hedeflerin gerçekleștirilmesine de yardımcı olmaktadır. Mikrofinans yoluyla yoksullukla mücadele hareketi, 1970'li yılların ortalarında Chitagong Üniversitesi ekonomi Profesörü Muhammed Yunus tarafından başlatılmıştır. Yoksulluğun çok yoğun olarak yaşandığı Bangladeş'te, halkın karşı karşıya olduğu açlık ve bu durum karşısında yaşadığı çaresizlik, Prof.Dr. Yunus'u ekonomik teorilerin öngördüğü modellerin ötesinde farklı çözüm arayışlarına yöneltmiştir. Yunus tarafından o yıllarda ortaya atılan çözüm önerileri, günümüzde Grameen tipi finansman modelinin temelini teşkil etmiş̧tir. İhtiyaç sahibi 42 kişiye verilen toplam 27 Dolar tutarındaki kredi ile başlatılan proje, 
günümüzde dünyanın birçok ülkesinde uygulanmakta olan dev bir finansman modeline dönüşmüştür (M. YUNUS, 2003, s.15-20.).

\section{Grameen Bank’ın Ortaya Çıkışı ve Gelişimi}

Grameen Bank, 1970'lerin ortalarında, Chittagong Üniversitesi'nde ekonomi profesörü olan Muhammad Yunus tarafından geliştirilen bir proje kapsamında ortaya çıkmıştır. Muhammad Yunus, daha sonraları gelişmekte olan ülkelerde yapılan araştırmalarca da desteklenen inceleme ve araştırmalar sonucunda, yoksul kesimin krediden yoksun kalmasının, bu kesimin ekonomik açıdan ilerlemesi önündeki en önemli kısıtlardan birisi olduğu yargısına varmıştır. Bu yargıdan hareket eden Yunus, teminat olmaksızın yoksullara kredi verilmesinin mümkün olduğunu ispat etmek istemiştir (Todaro ve Smith, 2006:241). Grameen Bankası, 1976 yılında yoksulların yeteneklerini değerlendirmek amacıyla Muhammed Yunus tarafından Bangladeş'te kurulmuş olan bir bankadır. Günümüzde bu model esasında, 81 ülkede faaliyet göstermektedir. Grameen Bankası'nın başlangıcı mikrokredi fikri olarak 1973 yılında Prof. Dr. Muhammed Yunus tarafından Bangladeş'in Çitagonk köyünde uygulanmaya başlamıştır. Muhammed Yunus; 42 aileye toplam 27 dolar borç vererek onların kendi paralarını kazanmalarını sağlamış ve bu insanların nispeten mutlu olduklarını, kendilerine güvenmeye başladıklarını ortaya koymuştur. 1979 yılına kadar Bangladeş Merkez Bankası ve diğer ticari bankaların desteği ile proje geliştirilmiş ve 1983'te Grameen Bank adı altında yoksullara kredi veren mikrokredi bankası kurulmuştur. Bangladeş'te Grameen Bankası'ndan 6.2 milyon kişi bu krediyi kullanarak kendi işlerini yapmaktadırlar.

\subsection{Grameen Bank’ın Amacı ve Hedefleri}

Grameen kelimesi, Bangladeş dilinde "kırsal" ya da "köy" anlamına gelmektedir. Grameen projesi 19761979 yılları arasında Jobra köyündeki başarılı uygulamaları sonucunda, Merkez Bankası ve Bangladeş'in diğer ticari bankaları tarafından desteklenmeye başlamıştır. 1979 yılında faaliyet alanını genişleten proje, Tangali Bölgesinde de kredi vermeye başlamıştır. Grameen Bank’ın amaçları (Grameen Bank, Erişim: 08.01.2007):

- Bankaların sunduğu finansal hizmetlerden yoksulların da faydalanmasını sağlamak,

- Yoksulların informal (biçimsel olmayan) kredi kullanıcıları tarafından sömürülmesini engellemek,

- Bangladeș'in kırsal kesimlerinde yaşayan işsizlere kendi işlerini kurma firsatı vermek,

- Uzun yıllardır süregelen "düşük gelir-düşük tasarruf-düşük yatırım”dairesi “düşük gelir-kredi desteğiyatırım-daha fazla gelir-daha fazla tasarruf-daha fazla yatırım-daha fazla gelir" olarak değiştirmek şeklinde özetlenmektedir.

\subsubsection{Grameen Bank Kredilerinin Kullanım Alanları}

Genel olarak, Grameen Bank kredi aktarım sisteminde borçlananlar, aldıkları krediyi kendi seçtikleri alanlarda kullanabilmektedirler. Çünkü yapılan incelemelerde, borçlananların genellikle iyi bilinen faaliyet alanlarına yatırım yapmak istedikleri ortaya çıkmıştır. Bu nedenle Banka çalışanları, yatırım yapılacak faaliyet alanının seçimi konusunda, üyelere herhangi bir yönlendirmede bulunmazlar. Ancak, sıkı bir izleme süreci mevcuttur. Grup başkanı ve banka çalışanı, verilen kredilerin faydalı bir şekilde kullanılıp kullanılmadığını görmek için borçlananları takibe alırlar (Sarker, 2001:8). Kredi, her bir grup üyesince 
belirlenen faaliyetlere yönelik olarak sağlanır ve üyeler bu faaliyetlerin seçiminde birbirlerine yardımcı olmaktadırlar. Hem seçilen faaliyetler hem de kredi miktarları grup ve merkez toplantılarında ele alınmaktadır (Khandker, 2006:68). Diğer taraftan, Grameen Bank'ın kredi müşterileri ağılıklı olarak topraksız köylülerden oluştuğu için, bankadan sağlanan krediler, genellikle kırsal kesimde bulunan, ancak çiftçiliğe yönelik olmayan faaliyet alanlarında kullanılmıştır. Nitekim tarımsal krediler, kredi işlemlerinin başladığı ilk yıllarda, Banka'nın kredi portföyünün çok küçük bir bölümünü oluşturmaktaydı. Ancak 1991 yılından sonra, gerek borçlananlardan gelen baskı, gerekse çalışanlarının artan ücretlerinden dolayı Banka'nın maliyetlerini azaltma kaygısıyla hareket etmesi, tarımsal faaliyetlerin daha fazla finanse etmeye yönlendirmiştir. Banka'nın 2010 yılı içerisinde en fazla kredi sağladığı faaliyet alanlarının başında tarım ve ormancılık gelmektedir. Bu alanda 2010 yılında 2.347 .446 kişiye verilen yaklaşık 23.5 milyar takalık borç, toplam kredi büyüklüğünün \%24.46'sını oluşturmaktadır. Bu alandaki kredilerin \%97,6'sı kadınlara, $\% 2,4$ 'tü ise erkeklere verilmiştir. Toplam kredilerin \%23,17'lik pay ile ticaret, \%20.32'yle hayvancılık ve balıkçılık, \%16,66'yla işleme ve üretim, yaklaşık \%11 ile mağazacılık, \%3,39'la hizmet ve en son sırada $\% 1,01$ oranıyla dilencilere yönelik geliştirilen seyyar satıcılık alanları takip etmektedir. Banka tarafindan verilen kredilerin alanlara göre dağılımı yıllara göre farklılık gösterse de kadın erkek arasındaki dağılım aynı oranlarda kalmaktadır. Bu da, kadınların tüm alanlarda iş yapma yeteneği olduğunu ortaya koymaktadır. Ancak, Grameen Banka'sının daha çok kadınlara yönelik çalıştıklarından erkek eşleri için kredi almış olabilecekleri de düşünülmesi ve araştırılması gerekmektedir.

\subsubsection{Grameen Bank'ın Finansal Yapısına Genel Bakış}

Dünya da yoksullukla mücadele eden kurumlar ve programların yanı sıra finansal sektör içinden de bir yoksul bankası olarak faaliyetini sürdürmekte olan Grameen Bankası ile ilgili tüm bilgiler verilmiştir. Daha önceki kısımlarda geniş olarak aktarılan bilgileri daha da açıklayıcı olması için söz konusu Banka'ya ait bilançosu ve varlığını sürdürebilmesi için en çok ihtiyaç duyduğu fon yapısı üzerinde durulacaktır.

Varlık Yapısı: Grameen Bank'ın, 1983 yılında 2.109 milyon dolar olan aktif büyüklüğü, 2010 yllında 12.7 milyar doları aşmış ve son 25 yılda, yaklaşı 6 kat büyümüştür. Banka'nın, krediler, mevduat yatırımı ve hazine bonoları gibi gelir getiren aktiflerinin toplam aktifleri içerisindeki payı ise, son 8 yıldır, $\% 90$ düzeyinde seyretmektedir. Ancak, bu gelir getirici aktiflerinin her birinin aktifler içerindeki payı, zaman içerisinde değişmiştir. Örneğin, mevduat yatırımlarının toplam aktifler içerisindeki payı, 1983 yllında $\% 15,5,1997$ yılında da yalnızca \%23 iken, 2009 yılında \%84,7; 2010 y1lında ise, \%87 düzeyinde gerçekleşmiştir. Kredilerin toplam aktifler içerisindeki payının da 1983'te \%62, 1997'de \%63.6, 2009'da $\% 54,7$ ve 2010 yılında \%54,5 olduğu görülmektedir. Banka'nın sabit varlıklarının toplam aktifler içerisindeki payı ise, 1983 'te $\% 1,17$ iken son yıllarda, \%1.4 ile \%3 arasında değişmiştir. Bu kapsamda, aktif kalemleri içerisinde mevduat yatırımlarının payının giderek artması, kredilerin oranının ise tersine azalması dikkat çekmektedir.

Kaynak Yapısı: Son yıllarda, Grameen Bank'ın kaynak yapısında da önemli değişimler gerçekleşmiştir. Bugün, Grameen Bank'ın fon kaynaklarının büyük kısmı, gerek üyelerden gerekse üye olmayanlardan sağlanan mevduatlardan oluşmaktadır. Bu durum, Banka'nın temel olarak iç kaynaklarına güvenmesini sağlayan, yerel tasarruf eğilimlerindeki değişimin bir göstergesidir. Buna göre, 1983 yılında sadece 777.713 dolar olan ve toplam kaynakların \%15'5ini oluşturan "mevduat ve diğer fonlar" kalemi, 2010 yllında 1.5 milyar dolar seviyesine ulaşmıştır. Zira, yıllar itibariyle sürekli artan bir görünüm sergileyen mevduat ve diğer fonlar kaleminin, 2010 yılında, toplam kaynaklar içindeki payı \%82.5'e ulaşmıştır. Grameen Bank'ın fon kaynaklarından biri olan diğer bankalardan ve yabancı kurumlardan borçlanmaları ise giderek 
azalmaktadır. Bu kalemin, toplam bilanço büyüklüğü içerisindeki payı, 1997 yılında \%15.5 düzeyindeyken; 2008 yılında \%2.09'a kadar gerilemiştir. Banka'nın, 2010 yılında diğer bankalardan ve yabancı kurumlardan aldığı borçların toplamı 22.574.621 dolardır. Oysa bu tutar, 2008 yılında 25.192 .353 dolar idi. Bu durum, Banka'nın kaynak yapısının değiştiğini gösteren etkenlerin başında gelmektedir. Diğer taraftan, ödenmiş sermaye, yedekler ve bağışlar toplamından oluşan ve finansal gücün en önemli göstergesi olarak kabul edilen sermaye büyüklüğünün, tüm kaynaklardan aldığı pay, son 10 yll içerisinde, $\% 7$ ila $\% 14$ aralığında değişkenlik göstermiştir. Sadece 2003 yılında, "genel ve diğer yedekler" kaleminin aşırı büyümesi, o yıl sermaye toplamının kaynaklar içerisinde aldığı payı \%30'a çıkarmış; ancak bu oran, 2008 'de $\% 7.34$ 'e ve 2010 'da da $\% 5.43$ 'e kadar gerilemiştir. Sermaye miktarının bu düşüklüğü, Grameen Bank'ın daha istikrarlı faaliyet yürütme kapasitesini zayıflatmaktadır (Khandker, Khalily ve Khan, 2007:60).

Sonuç

İstihdam, ekonomik büyümenin en temel belirleyicilerindendir. İstihdamdaki artış, üretimi arttıracak ve böylece ekonomik büyüme artacaktır (Kamacı, 2016:29). Grameen Bank'ın 2010 yılında sağladığı mikro girişim kredilerinin kullanım alanlarına göre dağılımı incelendiğinde, banka tarafından 2010 yılında kullandırılan 25.5 milyar takalık mikrogirişim kredisi içinde en büyük payı, \%28.8'i ticaret, \%19.93 ile hayvancılık ve balıkçılık \%18.11'lik payla mağazacılık, \%17.73 ile işleme ve imalat ve en az payla hizmet ve seyyar satıclık sektörü almıştır. Daha önceki bölümlerde de belirtildiği gibi yoksul nüfusun yoğun olduğu bölgelerin kırsal olması, banka müşteri portföyünün büyük bir kısmını bu bölgelerdeki müşterilerden oluşması nedeniyle alanlardaki kredi payı paylaşımında değişiklik olmamaktadır. Grameen Bank'ın finansal yapısını ilgilendiren bir başka konu da mali sürdürülebilirliktir. Buna göre Grameen Bank, borç verdiği her bir takanın maliyetini, en azından borçlanana ödettiği fiyatla eşitleyebildiği sürece (örneğin faiz oranlarıyla), mali olarak hayatta kalabilecektir (Khandker, 2006:70). Bu kapsamda Banka, mali sürdürülebilirliğini sağlamak amacıyla, borç alan yoksulları tasarrufa teşvik etmektedir. Zira, Banka'nın 1995 yılından itibaren kullandırdığı kredilerin \%90'ını, kendisine borçlananlardan ve hissedar mudilerden sağlanan faiz gelirleri ve mevduatlar ile finanse etmiştir. Grameen Bank, bu yolla, kırsal kesim tasarruflarının, şehirli elit kesime kaynak oluşturduğu, geleneksel finansal fon aktarım sistemini tersine çevirmeyi amaçlamıştır. Sonuçta Banka, köylerden toplanan mevduatın yine köylerdeki yoksullara borç olarak kullandırılmasına aracılık ederek, kendisini bu geleneksel sistemin dışında tutmuştur (Mainsah ve diğerleri, 2004:5).

Dünya uygulamalarına bakıldığında, mikrofinans modelinin gerek gelişmiş, gerekse gelişmekte olan birçok ülkede 30 yılı aşkın bir süredir başarıyla uygulandığı görülmektedir. Bu alanda yapılan birçok araştırma; mikrokredinin yoksul hane halklarının gelirlerine ciddi katkıda bulunduğunu, menkul ve gayrimenkuller edinmelerine yardımcı olduğunu ve bu bireylerin zaman zaman meydana gelen olağanüstü negatif gelişmelerden (doğal afetler, iktisadi krizler v.s.) daha az etkilenmelerine sebep olduğunu ortaya koymuştur. 1983 yilında Grameen Bank'ın kurulmasıyla kurumsal bir kimlik kazanan mikrofinans uygulaması, geçen zaman içinde, sistemi daha etkin hale getirme yolunda bir takım dönüşümler yaşamış ve bazı yenilikleri bünyesine katmıştır. Buna örnek olarak mikrosigorta uygulaması söylenebilir (Erhan Birgili, Nurhodja Akbulaev, 2010: s.305).

Kaynak: 
Aktan, Coşkun Can (2002), "Yoksullukla Mücadele Stratejileri”, Yoksullukla

Aktan, Coşkun Can ve İstiklal Yaşar VURAL (2002), "Yoksulluk: Terminoloji, Ankara.

Arpacıoğlu, Ö. Yıldırım, M. (2011). Dünya da ve Türkiye'de Yoksulluğun Analizi,

Bayındırlık ve İskan Bakanlığı (2009), Kentsel Yoksulluk, Göç ve Sosyal Politikalar, http://www.bayindirlik.gov.tr, (12.08.2011).

Birgili E., Akbulaev N., (2010), II. Uluslararası Sosyal Bilimciler Kongresi Orta Asya Ülkelerinde Mikrofinans Uygulamaları, 305.

Bıçkı, D. (2005). Kentsel Yoksulluğun Yapısal Faktörlerle Analizi: Ekonomik ve Politik Yapının Yeniden Örgütlenmesi: Karşılaştırmalı Bir Analiz.

Coşkun Can Aktan (ed.), (2002). Yosulluk Terminoloji, Temel Kavramlar Ve Ölçüm Yöntemleri, Yoksullukla Mücadele Stratejileri, Ankara: Hak-İş Konfederasyonu Yayınları.

Demir, S. (2006), Birleşmiş Milletler Kalkınma Programı İnsani Gelişme Endeksi ve Türkiye Açısından Değerlendirme”, DPT Sosyal Sektörler ve Koordinasyon Genel Müdürlüğü, Ankara.

Johannsen, J., \& Zeller, M. (2006, August). Operational Poverty Targeting by the Means of Proxy Indicators-The Example of Peru. In Contributed paper for presentation on the International Association of Agricultural Economists Conference, Gold Coast, Australia.

Kamacı, Ahmet. (2016). "Doğu Karadeniz’de İşgücü ve İstihdam.": Yönetim, Ekonomi, Edebiyat, İslami ve Politik Bilimler Dergisi, 14-32.

Kandemir, Orhan. (2011). "Tarımsal Destekleme Politikalarının Kırsal Kalkınmaya Etkisi." Ekonomi Bilimleri Dergisi 3.1

Khandker S.R., 2007. "Coping with flood: role of institutions in Bangladesh," Agricultural Economics, International Association of Agricultural Economists, vol. 36(2), pages 169-180, 03.

Khandker, S.R. (1996). Grameen Bank: Impact. Costs. and Program Sustainability. Asian Development Review. Cilt 14. Sayı 1.

Khandker, Shahidur R. \& Khalily, M. A. Baqui \& Samad, Hussain A., 2010. "Seasonal and extreme poverty in Bangladesh : evaluating an ultra-poor microfinance project," Policy Research Working Paper Series 5331, The World Bank.

Mainsah, E., Heuer, S. R., Kalra, A., \& Zhang, Q. (2004). Grameen Bank: Taking capitalism to the poor. Chazen Web Journal of International Business, 1-28.

Özge ve Metin Yıldırım (2011), "Dünyada ve Türkiye'de Yoksulluğun Analizi", Niğde Üniversitesi İ̈BF Dergisi, Cilt 4, Sayı 2, ss.60-76

Sarker, A.E. (2001). The Secrets of Success: The Grameen Bank Experience in Bangladesh. Labour and Management in Development Journal. Asia Pacific Pres: Cilt 2. Sayı 1.

Seyyar, A. (2002). Sosyal Siyaset Terimleri, Beta Yayınları, İstanbul.

Seyyar, A. (2003). Sosyal Siyaset Açısından Yoksulluğa Karşı Mücadele. Yoksulluk Sempozyumu, İstanbul: Deniz Feneri Derneği Yayınları, CI, 38-69. 
Şenses, F. (2001), Küreselleşmenin Öteki Yüzü Yoksulluk, 2.Basım,İletişim Yayınları, İstanbul.

Şenses, Fikret (2006), “Küreselleşmenin Öteki Yüzü: Yoksulluk”, 4. Baskı, Tarihi: 22.08.2001.

Todaro, J. B., \& Smith, M. (2006). Training library staff and volunteers to provide extraordinary customer service. Neal Schuman Pub.

Todaro, M. P., \& Smith, S. C. (2005). Economic Development 9th edition Addison Wesley.

Todaro, M.P. \& Stephen, C. S. (2002). Economic Development. 9.Basım, USA:Pearson

TÜİK İstatistikleri, http://www.tuik.gov.tr/Start.do. 2017

UNDP. (2011). Human Development Report 2010, http:/hdr.undp.org/en/, Erişim

Yunus, M. (2000). Banker to the Poor . The University Press Limited, Dhaka.

Yunus, M. (2002). Grameen Bank II: Designed to Open New Possibilities, October.

Yunus, M. (2003). Some Suggestions on Legal Framework for CreatingMicrocredit Banks, Grameen Bank, July.http://www.grameen.com/

http://www.grameen.com/index.php?option=com_content\&task=view\&id=179\&Itemid=424 